\title{
Application of Emoji on Social Media: its Impact among Youngsters
}

\section{OPEN ACCESS}

Manuscript ID:

ASH-2021-09024193

Volume: 9

Issue: 2

Month: October

Year: 2021

P-ISSN: 2321-788X

E-ISSN: 2582-0397

Received: 10.07.2021

Accepted: 28.08.2021

Published: 01.10.2021

Citation:

Chitra, V., and R.

Swaranalatha. "Application of Emoji on Social Media: Its Impact among Youngsters." Shanlax International Journal of Arts, Science and Humanities, vol. 9, no. 2, 2021, pp. 17-20.

DOI:

https://doi.org/10.34293/

sijash.v9i2.4193

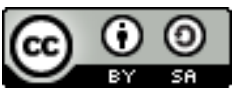

This work is licensed under a Creative Commons Attribution-ShareAlike 4.0 International License

\author{
V. Chitra \\ Associate Professor, PSG College of Arts \& Science, Coimbatore, Tamil Nadu, India
}

\section{R. Swaranalatha}

Associate Professor \& Head, PSG College of Arts \& Science, Coimbatore, Tamil Nadu, India

\begin{abstract}
The growth of communication shows a tremendous rise in today's environment. The latest and shortest form of communication tool used in social media is Emoji. Emoji's express the emotions of the user while in communication. This paper focuses on the use of Emoji on social media such as Facebook, Whatsapp and Instagram. The study results show that most of the users use Emoji's to save time and for an easy way of communicating their thought to the receiver.
\end{abstract}

Keywords: Emoji, Social media, Communication tool, Usage of Emoji's

\section{Introduction}

Effective Communication is a very mandatory element of our life. When we look back to history, communication is done through letters, oral, symbols, art etc. Today, because of advancements in technology, communication has become easier. Messages are transmitted in a fraction of seconds; distance is not a factor. Innovation in technology and Social media has brought a change like communication. The growth in communication began from letters, calls, emails, text messages and now evolved to its shortest and latest form of Emojis. Emojis are influencing the lives of people and the way they communicate with others. They represent everyday aspects of life. Due to this, it has brought unexpected popularity. Emojis lightened the mood and relaxed the mind of the youngsters. Social media applications are spending a lot of money on emojis and tactics to make them more attractive for their users. Emojis instantly deliver the emotion we want to express to the other person. Messages need not be typed long; instead, an emojis can say much more. This is leading to a decline in the usage of words and language. This paper focuses on the application of Emoji on social media and their impact on youngsters.

\section{Need for the Study}

This is a study mainly conducted for the new generation on how the impact is created among the growing youngsters of the society, particularly to the social media users. It is highly defined as a simple tool for communicating language and emojis for the faster communicative technique among the present and future youngsters. This is highly targeted in the minds of youngsters for a quick typing language. It is also helpful in faster communication with the expression of emojis. 


\section{Literature Review}

Tae-Woong Park, Si-Jung Kim, Gene Lee, in their study, finds the richness of instant messaging using emoticons and show that the instant messaging technique has replaced verbal communication to a larger extent. Petra Kralj Novak, Jasmina Smailovic, Borut Sluban, Igor Mozetic, in his study, focuses on another aspect-sentiment of emojis. And the author gives us a definite section, i.e. how they are being used in Twitter. It shows how modern communication has evolved by using emojis and how the users are targeted by social media. Hannah Miller, in his study, finds that Emojis are positive, but they can also cause miscommunication, and this causes problems on not understanding the emotion delivered. Ruth Filik, Alexandra Turcan and Amelia Turner, in his study, identifies how emoticons are used to clarify ambiguous and confusing messages, how they add more depth into conversations. Amy Ip, in his study, focuses on understanding the difference in a user's psychology of how they interpret different emojis and how positively or negatively they take it. A comparison of the effect of emoticons was made among people of varying age groups. The results showed that emojis did not increase the positivity, but they were more extreme, much more than punctuation marks.

\section{Scope for the Study}

This method of study has contributed to the easy way of communication. The brand new communication of emoji's leading way of expressing communication on social media like Facebook, Whatsapp, Instagram, Twitter and so on. The study has also made the average rate of users worldwide with the better way of communication among youngsters balanced according to the technology.

\section{Objectives of the Study}

- To identify the use of emojis while communicating on social media.

- To identify the most preferred emoji by youngsters for communicating.
- To identify the reason for using emoji on social media.

\section{Research Methodology}

The research design used in this study is descriptive. The sample size of the study is 110 respondents within the age group between 18 to 25 years. The collected data is analysed by using Simple Percentage Analysis, Chi-square test and ANOVA.

\section{Analysis and Results}

Table 1: Classification of Respondents Preferring the Type of Social Media

\begin{tabular}{|l|c|c|}
\hline $\begin{array}{c}\text { Social Media } \\
\text { Preference }\end{array}$ & $\begin{array}{c}\text { No. of } \\
\text { Respondents }\end{array}$ & $\begin{array}{c}\text { \% of } \\
\text { Respondents }\end{array}$ \\
\hline Facebook & 24 & 22 \\
\hline Whatsapp & 51 & 46.3 \\
\hline Instagram & 29 & 26.3 \\
\hline Others & 6 & 5.45 \\
\hline \multicolumn{1}{|c|}{ Total } & 110 & 100 \\
\hline
\end{tabular}

The above table shows that maximum of $46.3 \%$ of the respondent's use Emoji's in using Whatsapp. $26.3 \%$ of the respondents of the study use Emoji in communicating through Instagram. $22 \%$ of the respondents of the study use Emoji in communicating through Facebook.

Table 2: Reason for using Emoji among the Respondents

\begin{tabular}{|l|c|c|}
\hline $\begin{array}{c}\text { Reason for } \\
\text { Using Emoji }\end{array}$ & $\begin{array}{c}\text { No of. } \\
\text { Respondents }\end{array}$ & $\begin{array}{c}\text { \% of } \\
\text { Respondents }\end{array}$ \\
\hline Save time & 42 & 38.1 \\
\hline Bored typing & 34 & 31 \\
\hline Express emotions & 22 & 20 \\
\hline Shorten message & 11 & 11 \\
\hline \multicolumn{1}{|c|}{ Total } & 110 & 100 \\
\hline
\end{tabular}

The above table reveals that $38.1 \%$ of the respondents say that Emoji are used while communicating saves time.

Table 3: Benefits of using Emojis in Mobile Communication

\begin{tabular}{|c|c|c|c|c|c|}
\hline Statements & Strongly Agree & Agree & Neutral & Disagree & Strongly Disagre \\
\hline Understandable & 36 & 30 & 44 & 0 & 0 \\
\hline
\end{tabular}




\begin{tabular}{|l|c|c|c|c|c|}
\hline Enjoyable & 29 & 48 & 33 & 0 & 0 \\
\hline Fast & 30 & 43 & 28 & 9 & 0 \\
\hline Supportive & 22 & 36 & 43 & 9 & 2 \\
\hline Meets Expectation & 70 & 40 & 0 & 0 & 0 \\
\hline Practical & 25 & 41 & 40 & 4 & 0 \\
\hline Innovative & 26 & 42 & 40 & 2 & 0 \\
\hline Cluttered & 25 & 24 & 38 & 23 & 0 \\
\hline Unfriendly & 11 & 10 & 20 & 40 & 29 \\
\hline Boring & 9 & 10 & 10 & 49 & 32 \\
\hline Creative & 49 & 39 & 22 & 0 & 0 \\
\hline
\end{tabular}

The above table shows that $63.63 \%$ of the respondents say that Emoji usage in communication meets their expectations. Only $9.1 \%$ of the respondents say that Emoji is unfriendly and only $8.2 \%$ of the respondents feel that Emoji usage in communication is boring.

\section{Chi-square Analysis}

- Assessing the difference between Gender Vs agreeability regarding benefits of the use of Emojis in mobile communication

Null hypothesis $\left(\mathbf{H}_{\mathbf{0}}\right)$ : There is no significant difference between gender and agreeability regarding the benefits of using emojis in mobile communication.

Alternative hypothesis $\left(\mathbf{H}_{1}\right)$ : There is a significant difference between gender and agreeability regarding the benefits of using emojis in mobile communication. Level of Significance: 5\%

Table 4: Gender Vs Agreeability Regarding Benefits at the use of Emojis in Mobile Communication

\begin{tabular}{|c|c|c|c|}
\hline & t & df & Sig. (2-tailed) \\
\hline agreeability & 0.588 & 108 & 0.558 \\
\hline
\end{tabular}

\section{Conclusion}

The t-test value is 0.558 , which is more than a $5 \%$ level of significance. Hence we accept our null hypothesis, and we may infer that there is no significant difference between gender and agreeability regarding the benefits of using emojis in mobile communication.

- Assessing the association between Gender Vs opinion on how Emojis is important in the hands of youngsters nowadays

Null hypothesis $\left(\mathbf{H}_{\mathbf{0}}\right)$ : There is no association between gender and opinion on how emojis is important in the hands of youngsters nowadays.

Alternative hypothesis $\left(\mathbf{H}_{\mathbf{1}}\right)$ : There is an association between gender and opinion on how emojis is important in the hands of youngsters nowadays.

\section{Level of Significance: 5\%}

Table 5: Gender Vs Opinion on how Emojis is Important in the Hands of Youngsters Nowadays

\begin{tabular}{|l|l|l|l|}
\hline & value & df & Sig. \\
\hline Pearson Chi-Square & 82.164 & 2 & 0.000 \\
\hline No of Valid Cases & 110 & & \\
\hline
\end{tabular}

Conclusion: The Chi-Square value is 0.000 , which is less than a $5 \%$ level of significance. Hence we reject our null hypothesis, and we may conclude that there is an association between gender and opinion on how emojis is important in the hands of youngsters nowadays.

\section{ANOVA}

- Assessing the difference between Age Vs agreeability regarding benefits of the use of Emojis in mobile communication

Null hypothesis $\left(\mathbf{H}_{\mathbf{0}}\right)$ : There is no significant difference between age and agreeability regarding the benefits of using emojis in mobile communication.

Alternative hypothesis $\left(\mathbf{H}_{\mathbf{1}}\right)$ : There is a significant difference between age and agreeability regarding the benefits of the use of emojis in mobile communication.

Level of Significance: $5 \%$ 
Table 6: Age Vs Agreeability Regarding Benefits at the use of Emojis in Mobile Communication

\begin{tabular}{|c|c|c|c|c|c|}
\hline & Sum of Squares & df & Mean Square & F & Sig. \\
\hline Between Groups & 1.981 & 2 & 0.991 & 1.646 & 0.198 \\
\hline Within Groups & 64.392 & 107 & 0.602 & & \\
\hline Total & 66.373 & 109 & & & \\
\hline
\end{tabular}

Conclusion: The t-test value is 0.198 , which is more than a $5 \%$ level of significance. Hence we accept our null hypothesis, and we may conclude that there is no significant difference between age and agreeability regarding the benefits of Emojis in mobile communication.

\section{Conclusion}

The preceding analysis reveals that the majority of the respondents at the UG level and have some knowledge about applications of Emoji. Only a few respondents feel boring in using Emoji for communication. It gives a very clear understanding on recommending Emojis are highly recommended for mobile communication.

\section{References}

Dunlap, Joannna C., et al. "What Sunshine is to Flowers: A Literature Review on the Usage of Emoticons to Support Online Learning." Emotions, Technology, Design, and Learning, edited by Sharon Y. Tettegah and Martin Gartmeier, Academic Press, 2016, pp. 163182.

Filik, Ruth, etal. "SarcasmandEmoji: Comprehension and emotional impact." Quarterly Journal of Experimental Psychology, vol. 69, no. 11, 2016.

Ip, Amy. The Impact of Emoticons on Affect Interpretation in Instant Messaging, http:// www.amysmile.com/doc/emoticon_paper.pdf

Kralj Novak, Petra, et al. "Sentiment of Emojis." PLOS ONE, 2015.
Kejriwal, Mayank, et al. "An Empirical Study of Emoji usage on Twitter in Linguistic and National Contexts." Online Social Networks and Media, vol. 24, 2021.

Ljubesic, Nikola, and Darja Fiser. "A Global Analysis of Emoji Usage." Proceedings of the 10th Web as Corpus Workshop, 2016, pp. 8289.

Luor, Tainyi, et al. "The Effect of Emoji in Simplex and Complex Task-Oriented Communication: An Empirical Study of Instant Messaging." Computers in Human Behavior, vol. 26, no. 5, 2010, pp. 889-895.

Miller, Hannah. "Investigating the Potential for Miscommunication using Emoji." International Conference on Web and Social Media, 2016.

Park, Tae Woong, et al. "A Study of Emoticon Use in Instant Messaging from Smartphone." International Conference on HumanComputer Interaction, 2014, pp. 155-165.

Skovhholt, Karianne, et al. "The Communicative Functions of Emoticons in Workplace E-mails." Journal of Computer-Mediated Communication, vol. 19, no. 4, 2014, pp. 780797.

Suresh, Swathi. "The influence of Emoji on Communication using Social Media- A Quantitative Study among College Students of Mysuru." Research Journal of Humanities and Social Sciences, vol. 9, no. 1, 2018, pp. 158-162.

\section{Author Details}

Dr. V. Chitra, Associate Professor, PSG College of Arts \& Science, Coimbatore, Tamil Nadu, India.

Email ID: chitra.nehha23@gmail.com.

Dr. R. Swaranalatha, Associate Professor \& Head, PSG College of Arts \& Science, Coimbatore, Tamil Nadu, India 